\title{
Metallic Iron and Nickel in Cretaceous and Cenozoic Sediments: The Results of Thermomagnetic Analysis
}

\author{
Diamar M. Pechersky \\ Institute of Physics of the Earth, Russian Academy of Scienses, Moscow, Russia. \\ Email: diamar1@front.ru \\ Received December $6^{\text {th }}, 2009$; revised February $1^{\text {st }}, 2010$; accepted February $3^{\text {rd }}, 2010$.
}

\begin{abstract}
With the aid of thermomagnetic analysis (TMA) up to $800^{\circ} \mathrm{C}$ the composition and distribution of particles of native iron and Fe-Ni alloy was studied in 15 sections, Gams (Austria), Verhorechie and Selbuhra (Crimea), Kvirinaki and Tetritskaro (Georgia), Aimaki, Bass, Dzhengutaj, Madzhalis and Gergebil (North Caucasus, Russia), Klyuchi and Teplovka (Volga Region, Russia), Koshak (Kazakhstan), Kara-Kala and Khalats (Turkmenistan). The age of sediments varies from Miocene to Early Cretaceous. Iron particles are present at 521 samples out of 921 studied. Their percentage varies from $10^{-5} \%$ to $0.05 \%$. The distribution consists of two groups: 1) "zero" group (iron is not found by TMA); 2) group of logarithmic normal distribution with a differing modes. The global enrichment by iron particles in synchronous deposits of Miocene, Maastrichtian-Danian, Santonian and Cenomanian was discovered. With respect to nickel content, the iron particles fall into two groups: 1) nearly pure iron without nickel; and 2) iron with nickel content up to $20 \%$, with modal value of 5\%. The source of iron particles is the cosmic dust. Particles of pure nickel and the alloy containing more of $20 \%$ of nickel are very rare. Possibly, such particles are related mainly with impact events. A peak of elevated iron content with nearly constant nickel of 5-6\% was found in almost all studied sections. It is a global effect which is not dependent of place and time of deposition of iron particles.
\end{abstract}

Keywords: Cosmic Dust, Metallic Iron, Nickel, Fe-Ni Alloy, Meteorites, Sediments, Thermomagnetic Analysis, Curie Point

\section{Introduction}

Modern data on distribution of native iron and nickel in the cosmic dust is rather limited, since only "direct" methods of detecting such particles were used. Thermomagnetic analysis (TMA) up to $800^{\circ} \mathrm{C}$ was employed during petromagnetic (rock-magnetic) studies of sediments [1-7]. The increase of TMA temperature interval by $100^{\circ}$ has given the chance to observe a detailed picture of a distribution of metallic iron in space and time.

Thermomagnetic investigations of composition and distribution of particles of native iron and Fe-Ni alloy was performed in 15 sediment sections: Gams (Austria, Upper Maastrichtian-Danian, $48^{\circ} \mathrm{N}, 15.2^{\circ} \mathrm{E}$ ), Verhorechie and Selbuhra (Crimea, Barrem-Apt, Senomanian, $44.7^{\circ} \mathrm{N}$, $34^{\circ} \mathrm{E}$ ), Kvirinaki and Tetritskaro (Georgia, Miocene, Upper Maastrichtian-Danian, $\left.42^{\circ} \mathrm{N}, 43^{\circ} \mathrm{E}\right)$, Aimaki, Bass, Dzhengutaj, Madzhalis and Gergebil (North Caucasus, Russia, Cretaceous, 42.1-42.9 $\mathrm{N}, 46-47.9^{\circ} \mathrm{E}$ ), Klyuchi and Teplovka (Volga Region, Russia, Upper Maastrichtian-Danian, $51.9^{\circ} \mathrm{N}, 46.5^{\circ} \mathrm{E}$ and $52.2^{\circ} \mathrm{N}, 46.2^{\circ} \mathrm{E}$ ), Koshak (Kazakhstan, Mangyshlak, Upper Maastrichtian-
Danian, $39.5^{\circ} \mathrm{N}, 54^{\circ} \mathrm{E}$ ), Kara-Kala and Khalats (Turkmenistan, Upper Cretaceous, $38.47^{\circ} \mathrm{N}, 56.2^{\circ} \mathrm{E}$ and Miocene, $\left.38^{\circ} \mathrm{N}, 58.3^{\circ} \mathrm{E}\right)$.

The spatial spread of the objects, from Gams in the west to Khalats in the east, is approximately $3000 \mathrm{~km}$. It allows to evaluate the global character of accumulation of cosmic particles in coeval deposits. Detailed selection of samples from Cretaceous sequences helps to find out features of accumulation of particles in time.

\section{Methods of Petromagnetic Studies}

Petromagnetic studies included measurements of sample magnetization and its dependence upon temperature, i.e. thermomagnetic analysis (TMA). TMA was carried out with the aid of Curie express balance [8]. The curves of $M(T)$ after the first and second heating to $800^{\circ} \mathrm{C}$ were obtained for all samples. It is possible to analyze distribution of Curie points. It is known that in particles of cosmic iron the basic impurity is nickel. Converting $\mathrm{Cu}-$ rie points into Ni content facilitates subsequent comparison of TMA data with those of microprobe and other analyses. 
For this purpose, we assumed a linear dependence of Curie points on Fe-Ni alloy compositions. Then the nickel content will be defined by the simple formula:

$\mathrm{Ni}($ wt. $\%)=0.243\left(770-T_{C}\right)$,

where 770 is the Curie point of iron, $T_{C}$ is a Curie point of the sample. This assumption has to be checked up. It is known that the Ni-Fe alloys with nickel content of less than $30 \%$ preserve the ordered $\alpha$ - phase with body-centred lattice close to the room temperature. $\alpha$ - phase transforms into $\gamma^{\prime}$ - phase with ordered face-centred lattice and $\gamma$ - phase with disordered face-centred lattice at higher concentrations of nickel and/or at higher temperature [9-11]. In such $\gamma$ and $\gamma^{\prime}$ - alloys, Curie points deviate from the above linear dependence, "underestimates" being more often than "overestimates" (Table 1). For example, invar $(36 \% \mathrm{Ni})$ has $T_{C}=230-270^{\circ} \mathrm{C}$, i.e. below Curie point of pure nickel $\left(358^{\circ} \mathrm{C}\right)$, but increases to $400^{\circ} \mathrm{C}$ under mechanical stress [12]. There are apparent "Curie points" as a result of transformation $\alpha \rightarrow \gamma$ at sample heating and $\gamma \rightarrow \alpha$ transformation at its cooling. Such situations mainly occur in Fe-Ni alloys of intermediate composition, with nickel of $>20 \%$ and $<80 \%$. For them, appreciable deviations in the estimation of nickel content with the aid of linear dependence $T_{C}-\mathrm{Ni}$ are common (Table 1).

In our case, it was more important not to understand the nature of such deviations, but to address two topics: 1) application the linear dependence $T_{C}-\mathrm{Ni}$ to the natural meteorites containing Fe-Ni alloys of intermediate composition, and 2) distribution of particles of a Fe-Ni alloy of intermediate composition in a cosmic dust.

To answer the first question, the data from papers [10, $13,14]$ has been used, where both microprobe analysis data and TMA results for samples of metal meteorites and metal inclusion in stone meteorites are available
(Table 2). Samples contain kamacite ( $\alpha$ - phase), tetrataenite $\left(\gamma^{\prime}-\right.$ phase $)$ and taenite $(\gamma$ - phase $)$ in different proportion. Appreciable divergences were noted only for two samples of alloys of intermediate composition: Yamato79069 and San-Cristobal. Hence, the use of linear dependence of $T_{C}$ - Ni for definition of the nickel concentration on TMA is admissible as the first approximation.

To answer the second question, we collected the data on composition of metal particles in the cosmic dust from the icecaps of Antarctica and Greenland, deep-sea ocean sediments, Pleistocene sediments of Canada, Eocene limestone of Tuamotu, the deposits from the area of Tunguska catastrophe, and sediments at the $\mathrm{K} / \mathrm{T}$ boundary in Gams [1,15-17]. Figure 1 shows that the particles with nickel content of $>20 \%$ and $<80 \%$ are very rare. For the other compositions, the estimation of the percentage of nickel content with the linear dependence $T_{C^{-}}$ $\mathrm{Ni}$ is quite applicable.

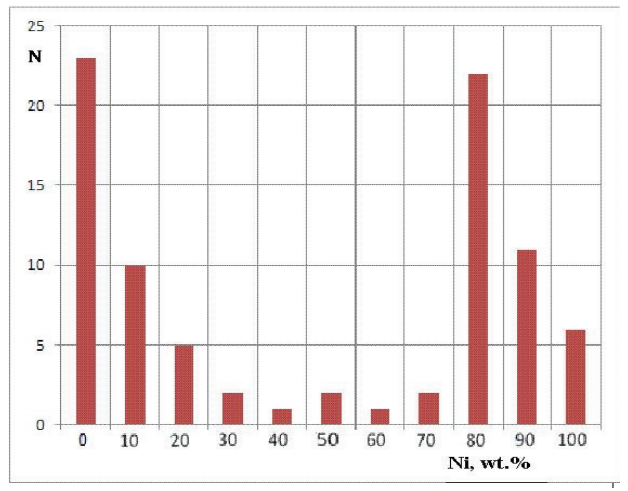

Figure 1. The histogram of nickel content in Ni-Fe particles from cosmic dust. $N$ is number of cases. Data $[1,15-17]$

Table 1. Comparison of nickel content in artificial NiFe alloys (wt.\%) with estimations on TMA

\begin{tabular}{llll}
\hline Mark of an alloy & Composition of alloy & Curie point, ${ }^{\circ} \mathrm{C}$ & $\mathrm{Ni}$, wt.\% on TMA \\
\hline Vacaperm & Ni100 & 400 & 90 \\
cryoperm & Ni90Fe10 & 430 & 83 \\
M7904 & Ni80, Mo5, Fe15 & 443 & 80 \\
Ni80 & Ni80Fe20 & 560 & 81 \\
Supermuniperm & Ni80Mn5Fe15 & 410 & 87 \\
Perm77 & Ni77, Mo4, Cu4,4 Fe14 & 410 & 81 \\
M75 & Ni75, Cr2, Cu5, Fe18 & 438 & 41 \\
Ni60 & Ni60Fe40 & 600 & 58 \\
Carpenter & Ni55Fe45 & 530 & 58 \\
AlloyNi50 & Ni52Fe48 & 530 & 66 \\
AlloyNi50 & Ni50Fe50 & 500 & 58 \\
Ni50 & Ni50Fe50 50 & 73 \\
M50 & Ni48, Fe52 & 530 & 73 \\
Nifemax & Ni48Fe52 & 471 & 100 \\
Ni40 & Ni40Fe60 & 470 & $?$ \\
Normaperm & Ni36Fe64 & 356 & $?$ \\
Invar & Ni36Fe64 & 240 & 96 \\
Invar & Ni36Fe64 & 230 & $?$ \\
Invar film standard (1) & Ni36Fe64 & 375 & 90 \\
Invar film after stress (2) & Ni36Fe64 & 250 & $?$ \\
Superinvar & Ni32Co5Fe63 & 400 & 39 \\
AlloyNi30 & Ni30Fe70 & 279 & \\
\hline
\end{tabular}


Table 2. Comparison of percentage nickel and iron in meteorites according to a microprobe and TMA data

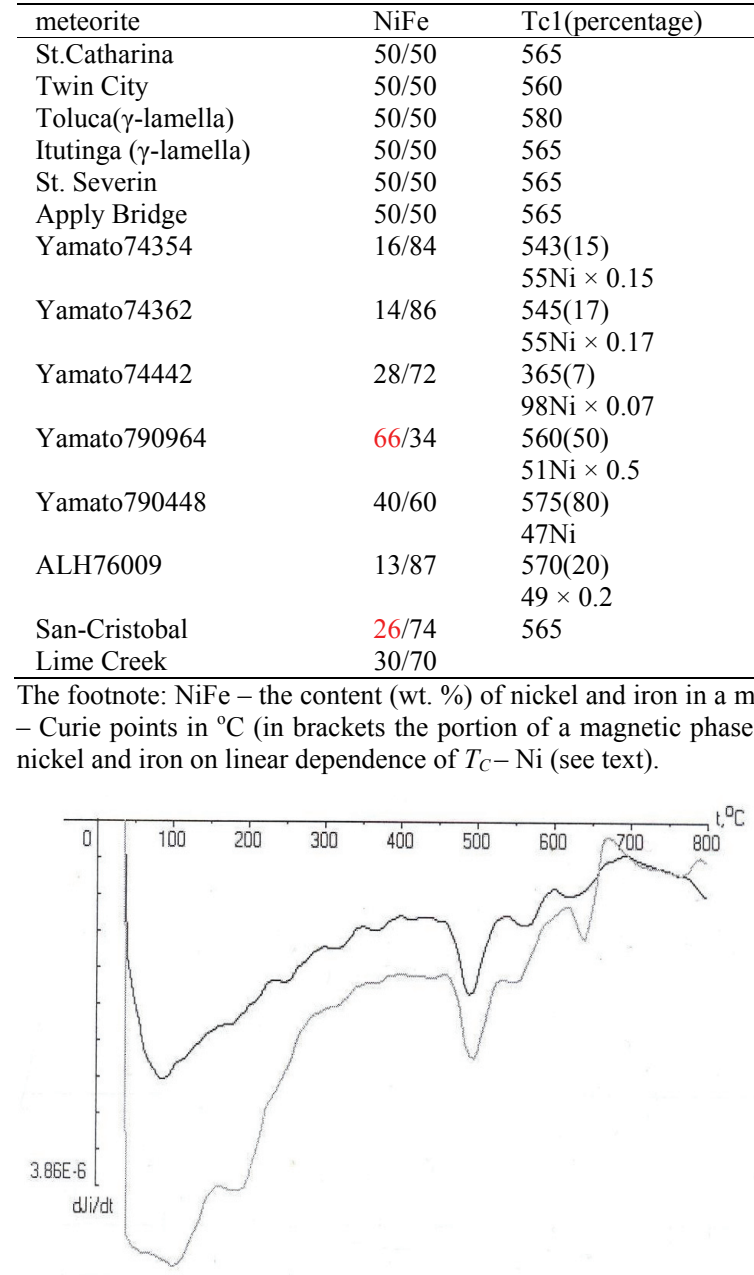

(1)

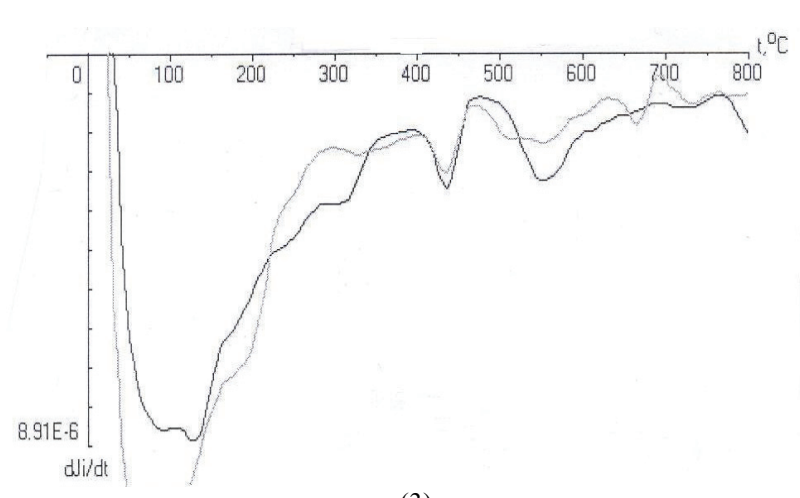

(3)

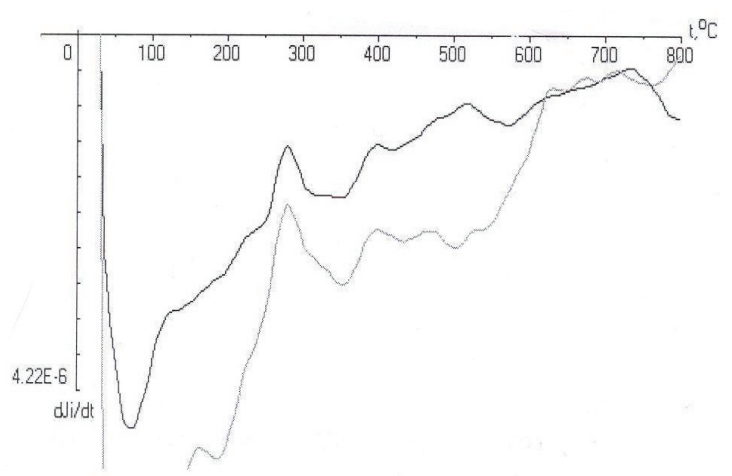

(2)

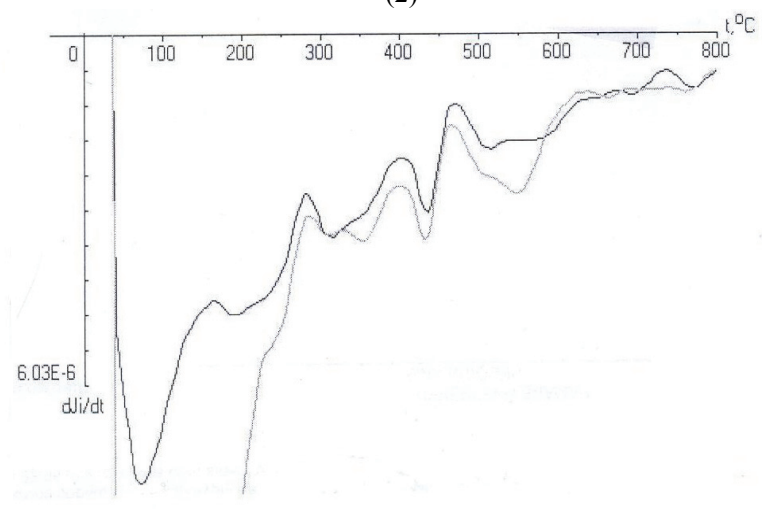

(4)

Figure 2. Examples of $\mathrm{dM} / \mathrm{dT}$ curves at which there are the Ni-Fe alloy signs. From top to down dM/dT curves for samples: 1- sample 2029-100 (Bass, $\left.T_{C}=500^{\circ} \mathrm{C}\right), 2$ - sample 2029-110 (Bass, $\left.T_{C}=365^{\circ} \mathrm{C}\right), 3-$ sample 2035-7 $\left(\right.$ Aimaki, $\left.T_{C}=445^{\circ} \mathrm{C}\right), 4-$ sample 2562-4 (Selbuhra, $T_{C}=440^{\circ} \mathrm{C}$ ). Bold-faced line is the $\mathrm{dM} / \mathrm{dT}$ curve of first heating; thin line is the curve of second heating

Another problem is that detecting $\mathrm{Fe}-\mathrm{Ni}$ alloys between $360^{\circ} \mathrm{C}$ and $680^{\circ} \mathrm{C}$ is very difficult, as their Curie points and those for the hemoilmenite and titanomagnet- ite series overlap. For an identification of such $\mathrm{Ni}-\mathrm{Fe}$ alloys, the samples have been chosen, in which Curie points are reproducible upon the second heating, and the 
contribution of these magnetic phases in magnetization did not change noticeably (Figure 2). This provision allows to assume that such samples contain particles of $\mathrm{Ni}-\mathrm{Fe}$ alloy with nickel from $100 \%\left(T_{C}=360^{\circ} \mathrm{C}\right)$ to $27 \%$ $\left(T_{C}=660^{\circ} \mathrm{C}\right)$. Really, magnetic minerals like pyrrhotite, titanomagnetite, and hemoilmenite are unstable and are oxidized during heating to $800^{\circ} \mathrm{C}$, are destroyed and/or homogenized and their Curie points are decreased; hence their contribution to sample magnetization varies greatly.

To estimate the content of native iron, Ni-Fe alloy, magnetite + titanomagnetite, the contribution of each mineral into magnetization $M$ was determined using the $M(T)$ curves and, then, it was divided by the specific saturation magnetization of each mineral. The values of $M_{\mathrm{s}}=90 \mathrm{Am}^{2} / \mathrm{kg}$ for magnetite + titanomagnetite with $T_{C}$ $=540-580^{\circ} \mathrm{C}$, and $M_{\mathrm{s}}=200 \mathrm{Am}^{2} / \mathrm{kg}$ for iron with $T_{C}=$ $700-770^{\circ} \mathrm{C}$ was used. The linear dependence $M_{s}$ between nickel $\left(M_{s}=56.7 \mathrm{Am}^{2} / \mathrm{kg}\right)$ and iron $\left(M_{s}=212 \mathrm{Am}^{2} / \mathrm{kg}\right)$ was accepted for Ni-Fe alloy [9]:

$$
M_{s}(\mathrm{Ni}-\mathrm{Fe} \text { alloy })=56.7+0.37\left(T_{C}-360\right) \text {. }
$$

The contribution of a mineral into bulk magnetization cannot be estimated with the accuracy of better than $10 \%$. Accordingly accuracy for iron and alloy particles content cannot be better. The accuracy of Curie point determination is $\sim 5^{\circ}-10^{\circ}$, which corresponds to a nickel admixture of $1-2 \%$. The lack of the linear dependence of $T_{C}-\mathrm{Ni}$ and the limited accuracy of TMA are compensated by the simplicity of sample preparation and their TMA, allowing quick acquisition of large datasets.

The content of magnetite and titanomagnetite were determined to take into account re-deposition during accumulation of iron particles. Their formation and accumulation, unlike native iron, has a terrestrial origin. The coefficients of linear correlation of iron and magnetite + titanomagnetite were calculated (Table 3).

Sequences of deposition of all sections are translated into a time for convenience of their comparison as follows: it was assumed that the sediments accumulated with a constant velocity during each stratigraphic stage.

Table 3. Coefficients of linear correlation between particles of magnetite + titanomagnetite and iron

\begin{tabular}{cc}
\hline Gams & 0,048 \\
Selbuhra & $-0,034$ \\
Verhorechie & $-0,319$ \\
Kvirinaki & $-0,041$ \\
Tetritskaro & 0,068 \\
Klyuchi + Teplovka & $-0,198$ \\
Aimaki & 0,147 \\
Dzhengutaj & 0,093 \\
Madzhalis & $-0,094$ \\
Bass & $-0,077$ \\
Gergebil & $-0,083$ \\
Kara-Kala & 0,187 \\
Khalats & $-0,212$ \\
Koshak & $-0,206$ \\
\hline
\end{tabular}

This velocity was defined by dividing the duration of a stage by its thickness. Then, the age of each sampling point was defined by multiplying the distance (thickness) to the stage boundary by the sedimentation velocity. The stage ages were taken from the geological time scale2008 [18].

\section{Results of Thermomagnetic Studies and Discussion}

Content of metallic particles in sediments. The particles of native iron were found in 521 samples out of 901 studied, their concentration ranging from $10^{-5} \%$ to $0.05 \%$. The bimodal distribution of concentration of iron particles is usually clearly visible for separate sections, areas, and the sum of the data (Figure 3): the first set with the "zero" mode comprises the deposits, in which iron is absent (it is not found out by TMA); distribution of such sediments in the studied sections is irregular. The second set has more often lognormal distribution with the slightly age-dependent modes: the Late Cretaceous modes are $\sim 0.05-0.1 \times 10^{-3} \%$ (Gams, Crimea, Caucasus, Mangyshlak, and Kopetdag), the Early Cretaceous mode for the North Caucasus is $0.15 \times 10^{-3} \%$ (Gergebil), and the largest modal values of $0.5 \times 10^{-3} \%$ (Khalats) and $3 \times 10^{-3} \%$ (Kvirinaki) are for Miocene sediments.

Four types of accumulation of metallic particles in the sediments are recognized:

Dotty type: the increased iron content is found in one sample, in a "dot", and is absent in the adjacent samples. This type has a random character and can result from the primary fall of iron into the sediment and from its re-deposition.

Local type: the increased content of iron is found in a series of adjacent samples from a section and cannot trace from section to section. Such local accumulation of iron can occupy a long enough interval of time. Most likely, it is combination of primary accumulation and secondary re-deposition. Example of long non-uniform local primary accumulation of iron is the Bass section in the interval from $81 \mathrm{Ma}$ to $72 \mathrm{Ma}$. An example of long mainly secondary accumulation of iron as a result of re-deposition is the Kara-Kala section in interval from 95 Ma to $99 \mathrm{Ma}[7]$.

Regional type: the enrichment by iron is found in synchronous intervals at several sections in a region. It is unlikely that it is a result of re-deposition, which was synchronous over a wide area. The regional effect of enrichment by iron of sediments becomes more clearly visible if to combine all studied sections (Figure 4).

Global type: the enrichment by iron is found in synchronous intervals at several sections from different remote regions.

It is possible to recognize the following intervals of regional and global enrichment by iron (Figure 4):

1) $12-13 \mathrm{Ma}$, the Middle-Late Miocene. The iron con- 


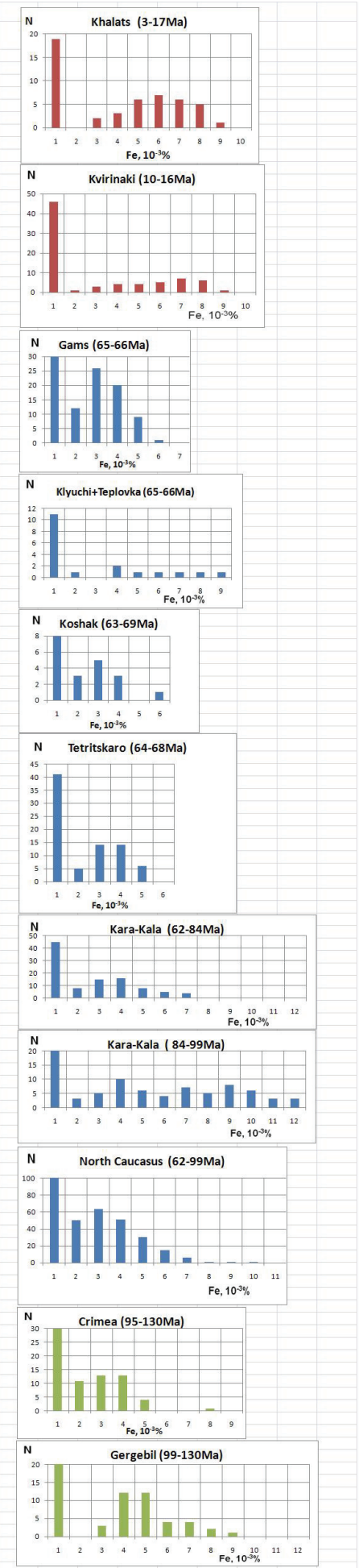

Figure 3. Histograms of iron particles concentrations in the studied sections. Intervals of iron concentrations (logarithmic scale): $1-0-0.01\left(10^{-3} \%\right) ; 2-0.01-0.03 ; 3-0.03-0.07 ; 4$ - 0.07-0.15; 5 - 0.15-0.31; 6 - 0.31-0.63; 7 - 0.63-1.27; 8 $1.27-2.55 ; 9-2.55-5.11 ; 10-5.11-10.23 ; 11-10.23-20.49$; 12 - 20.49-54 $\left(10^{-3} \%\right)$. Histograms are arranged on age from Miocene to Early Cretaceous tent that reaches $4 \times 10^{-3} \%$ is found at two sections (Khalats and Kvirinaki) that are more than $1500 \mathrm{~km}$ apart.

2) 64-67 Ma, Early Danian-Late Maastrichtian. The iron content that reaches $4 \times 10^{-3} \%$ is found in the Gams, North Caucasus, Teplovka sections, but isn't detected in the Crimea, Tetritskaro, and Koshak sections.

3) $84-86 \mathrm{Ma}$, Santonian. The increased iron concentration is found at five sections that are more $1000 \mathrm{~km}$ apart, with the maximum content ranging from $0.2 \times 10^{-3} \%$ (Madzhalis) to $2.9 \times 10^{-3} \%$ (Kara-Kala). This interval nearly coincides with the upper boundary of the Dzhalal paleomagnetic hyperchron (the interval of the geomagnetic field without reversals, $125-85 \mathrm{Ma}$ [19]). The lower boundary of the Dzhalal hyperchron is not defined accurately, probably because of sparse sampling at the Gergebil (Caucasus) and Verhorechie (Crimea) sections (Figure 4).

4) 94-96 Ma, Late Cenomanian. The increased iron concentration is found at the Aimaki (94.9-95.6 Ma) and Kara-Kala (93.8-97.4 Ma) sections that are more than $1000 \mathrm{~km}$ apart. With a less certainty, this interval can be related to the global enrichment by iron because of some role of iron re-deposition in the lower parts of both sections [7].

The wide spatial distribution of iron particles and global character of the above noted intervals of the increased iron concentration testifies to the cosmic dust as their main cause. The iron particles fell on the Earth surface irregularly and probably came from different sources, as is indicated by the bimodal distribution of their concentrations (Figure 3).

In contrast to iron particles, the particles of $\mathrm{Ni}-\mathrm{Fe}$ alloy with $>20 \% \mathrm{Ni}$ are rare, their concentration does not correlate with the concentration of iron particles $(r=-0.045)$. Appreciable correlation with the magnetite + titanomagnetite concentration $(\mathrm{r}=0.7)$ in the sediments may mean that the noticeable part of these particles is not a $\mathrm{Ni}-\mathrm{Fe}$ alloy, while the terrestrial minerals, like titanomagnetite and hemoilmenite, are fully preserved after heating to $800^{\circ} \mathrm{C}$, which is unlikely. Otherwise, these are the particles of a Ni-Fe alloy that were re-deposited together with terrestrial minerals. Such a sharp difference in the quantity and accumulation conditions between iron and $\mathrm{Ni}-\mathrm{Fe}$ alloy particles and the absence of correlation between their contents most likely testifies to their different origin. If the first are produced by cosmic dust fall on the Earth surface, the second are possibly connected with impact events. Irrespective of the reliability of detecting $\mathrm{Ni}-\mathrm{Fe}$ alloy particles, it is possible to assert that their concentration is likely to be below $10^{-5} \%$ (i.e., below of sensitivity threshold of TMA) in the cosmic dust.

Composition of metallic particles. Judging by the $\mathrm{Cu}-$ rie points, composition of iron particles varies approximately in the same range from $680^{\circ} \mathrm{C}$ to $780^{\circ} \mathrm{C}$ in all sections that corresponds to Ni-content from $22 \%$ to zero 


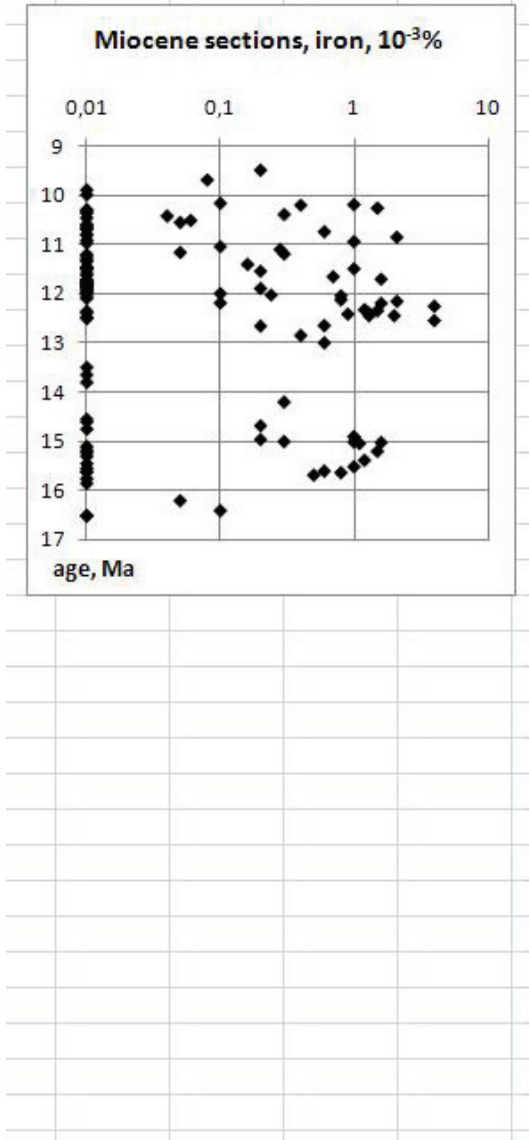

(a)

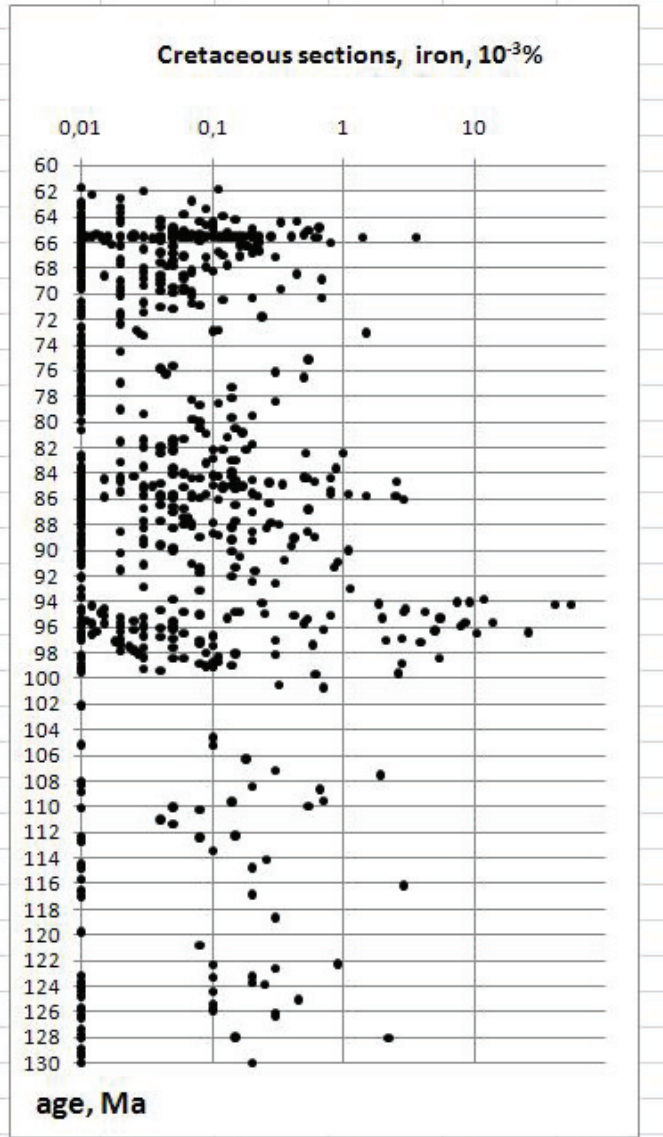

(b)

Figure 4. Iron distribution in (a) Miocene and (b) Cretaceous sediments. The sum of the data

(Figure 5). From $T_{C}=690^{\circ} \mathrm{C}$ to $360^{\circ} \mathrm{C}$, the number of particles sharply decreases, they are absent altogether. Really, just 46 samples with Curie points of $360^{\circ} \mathrm{C}$ to $660^{\circ} \mathrm{C}$, and hence probably containing particles of a $\mathrm{Ni}-\mathrm{Fe}$ alloy, are found (Table 4, Figure 5). The errors in detection of $\mathrm{Ni}-\mathrm{Fe}$ alloy are quite probable, and so the proven cases of Ni-Fe alloy cannot exceed the above number. The rarity of Ni-Fe alloys of intermediate composition among metal particles of cosmic dust is confirmed with direct measurements of composition of dust particles (Figure 1). Dust particles of pure nickel (Ni80$100 \%$ ) were met indeed (Figure 1), but practically all of them are from one point of the $\mathrm{K} / \mathrm{T}$ boundary layer in the Gams section [1].

Figure 5 demonstrates that the distribution of iron particles composition falls into two groups (not counting the "tail" in the interval $350^{\circ} \mathrm{C}-660^{\circ} \mathrm{C}$ ): 1) pure iron without nickel addition and 2) nearly lognormal distribution with the mode of nickel of $5 \%$. Bimodal distribution of particles of iron, probably, reflects different sources of pure iron and iron with the nickel impurity.

The second set with the mode Ni of 5\% is sufficiently proven by the data on composition of dust particles
(Figure 1). The first set of pure iron agrees with the data on lunar samples. For example, metal particles from the lunar material such as volcanic glass, basalts and breccias that was delivered by Apollo 11 and 12 consist mainly of nearly pure iron [20-29]. Curie points close to $770^{\circ} \mathrm{C}$ prevail, with average $T_{C}=765^{\circ} \mathrm{C}$. It is quite probable that it is specificity of lunar magmatic rocks. Fragments of meteorites, which have been picked up on the Moon during the Apollo missions, contain Fe-Ni alloys of intermediate composition that are usual for metal meteorites. Numerous microspherules (products of impacts) contain of nickel from $<1$ to $>20$ wt. \% [29-31]. Irreversible character of heating-cooling $M(T)$ curves, peculiar for $\alpha-\gamma$ transformation in Fe-Ni alloys, was marked.

Visible regularities in Curie point distribution and, accordingly, the nickel content in iron particles, were not found between sections. The compositions of iron particles form a diffuse cloud (Figure 6(a)), which is typical for the cosmic dust. Nearly constant smoothed values of $\mathrm{Ni}$ content are observed in the 110-60 Ma interval (Figure 6(b)). They vary within $6-8 \%$, i.e. within the error limits of Curie point estimation. The average content of nickel is $5 \%$ in Lower Cretaceous and Miocene sediments. The 


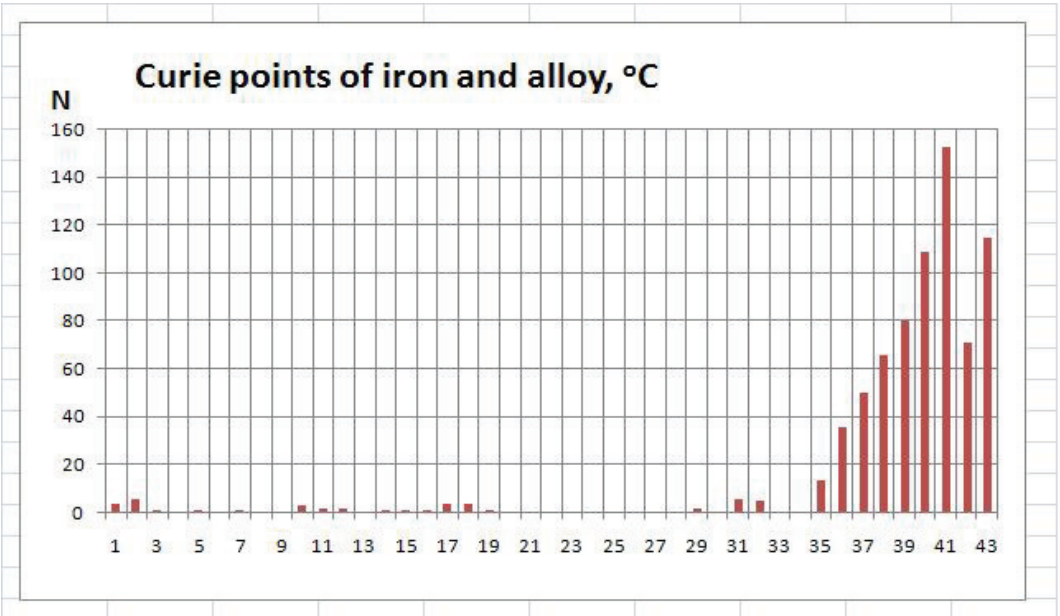

Figure 5. The histogram of distribution of Curie points (the content of nickel impurity in iron particles $\pm 1 \%$ ). The sum of the data. $1-350^{\circ} \mathrm{C}(100 \% \mathrm{Ni}) ; 2-360^{\circ} \mathrm{C}(100 \% \mathrm{Ni}) ; 3-370(97.6 \% \mathrm{Ni}) ; 5-390(92.7 \% \mathrm{Ni}) ; 7-410(87.8 \% \mathrm{Ni}) ; 10-440^{\circ} \mathrm{C}$ $(80.5 \% \mathrm{Ni}) ; 11-450(78.1 \% \mathrm{Ni}) ; 12-460^{\circ} \mathrm{C}(75.6 \% \mathrm{Ni}) ; 14-480^{\circ} \mathrm{C}(70.8 \% \mathrm{Ni}) ; 15-490^{\circ} \mathrm{C}(68.3 \% \mathrm{Ni}) ; 16-500^{\circ} \mathrm{C}(65.9 \% \mathrm{Ni}) ;$ $17-510^{\circ} \mathrm{C}(63.4 \% \mathrm{Ni}) ; 18-520^{\circ} \mathrm{C}(61 \% \mathrm{Ni}) ; 19-530^{\circ} \mathrm{C}(58.6 \% \mathrm{Ni}) ; 29-6^{\circ} 0^{\circ} \mathrm{C}(34.2 \% \mathrm{Ni}) ; 31-6^{\circ} 0^{\circ} \mathrm{C}(29.3 \% \mathrm{Ni}) ; 32-660^{\circ} \mathrm{C}$ $(26.8 \% \mathrm{Ni}) ; 35-6^{\circ} \mathrm{C}(19.5 \% \mathrm{Ni}) ; 36-7^{\circ} 0^{\circ} \mathrm{C}(17.1 \% \mathrm{Ni}) ; 37-710^{\circ} \mathrm{C}(14.6 \% \mathrm{Ni}) ; 38-720^{\circ} \mathrm{C}(12.2 \% \mathrm{Ni}) ; 39-730^{\circ} \mathrm{C}(9.8 \% \mathrm{Ni})$; $40-740^{\circ} \mathrm{C}(7.3 \% \mathrm{Ni}) ; 41-750^{\circ} \mathrm{C}(4.9 \% \mathrm{Ni}) ; 42-760^{\circ} \mathrm{C}(2.4 \% \mathrm{Ni}) ; 43-770^{\circ} \mathrm{C}(0 \% \mathrm{Ni})$

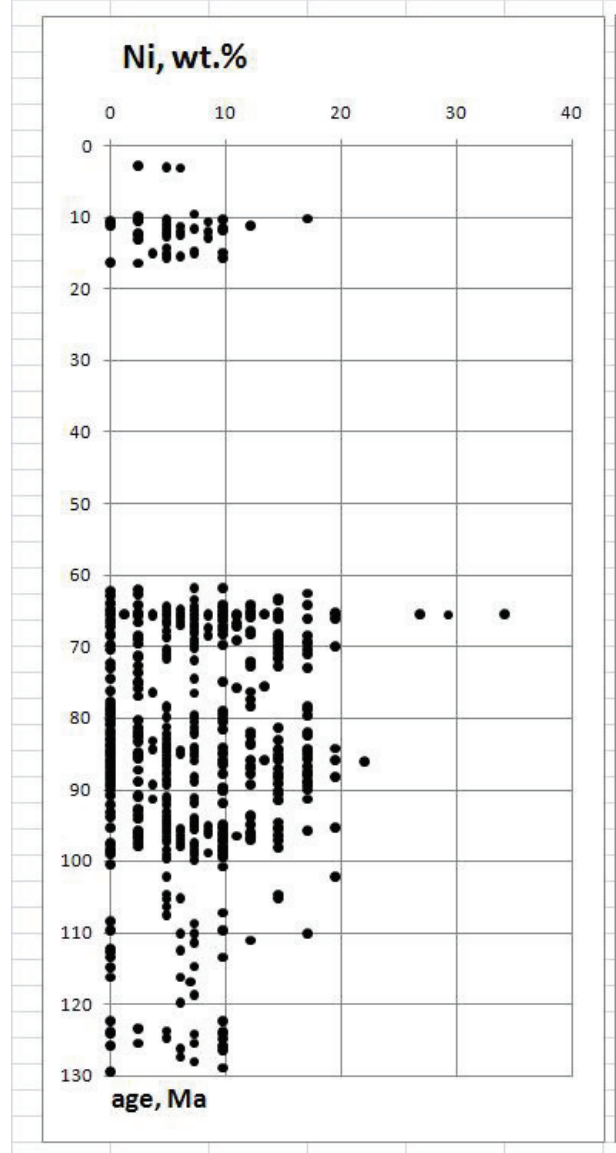

(a)

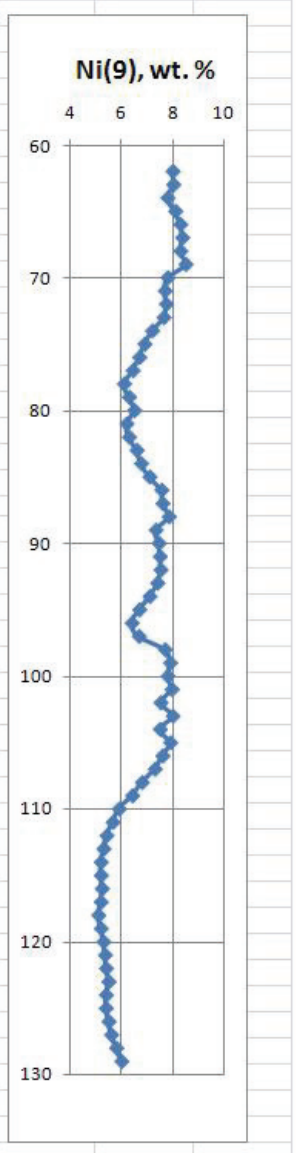

(b)

Figure 6. The distribution of contents of nickel impurity in iron particles depending on age of sediments. (a) The sum of the data; (b) Result of their smoothing. Interval of smoothing is 9 million years; a step is 1 million years 
Table 4. Ni-Fe-alloys in sediments

\begin{tabular}{|c|c|c|c|c|c|c|c|c|c|c|}
\hline section & Sample & $T_{C}$ & $\% \mathrm{Ni}$ & $\mathrm{Ni}$ & $\mathrm{Fe}$ & MT & $\mathrm{Ma}$ & $\mathrm{N}$ & $\mathrm{N}(\mathrm{Fe})$ & $\mathrm{N}(\mathrm{Ni})$ \\
\hline Aimaki & $2035-7$ & 450 & 78,5 & 0,11 & 0,09 & 1 & 99,06 & 112 & 60 & 1 \\
\hline \multirow[t]{2}{*}{ Bass } & $2029-110$ & 370 & 97 & 0,1 & 0 & 0,4 & 62,78 & 104 & 57 & 2 \\
\hline & $2029-100$ & 500 & 66,6 & 0,08 & 0,01 & 0,3 & 64,96 & & & \\
\hline \multirow[t]{4}{*}{ Gergebil } & $2038-206$ & 460 & 76,2 & 0,12 & 0 & 0,9 & 110,13 & 44 & 36 & 4 \\
\hline & 83 & 380 & 93 & 0,4 & 0 & 2 & 123,8 & & & \\
\hline & 31 & 455 & 77,4 & 0,3 & 0 & 24,5 & 127,36 & & & \\
\hline & 6 & 360 & 100 & 0,35 & 0 & 23,2 & 129,43 & & & \\
\hline \multirow[t]{2}{*}{ Madzhalis } & $2061-48$ & 440 & 81 & 0,02 & 0 & 0,7 & 86,1 & 57 & 39 & 2 \\
\hline & 37 & 365 & 98 & 0,05 & 0 & 0,3 & 87,2 & & & \\
\hline \multirow[t]{2}{*}{ Dzhengutaj } & $2057-78$ & 445 & 79,7 & 0,04 & 0,8 & 1,28 & 84,4 & 13 & 8 & 2 \\
\hline & 19 & 455 & 77,4 & 0,03 & 0,03 & 1,3 & 89,5 & & & \\
\hline \multirow[t]{3}{*}{ Karakala } & $2048-128$ & 455 & 77,4 & 0,13 & 0,04 & 6,3 & 69,72 & 181 & 98 & 3 \\
\hline & 138 & 450 & 78,5 & 0,05 & 0,03 & 2 & 70,64 & & & \\
\hline & 175 & 440 & 81 & 0,01 & 0,01 & 8,6 & 74,5 & & & \\
\hline \multirow[t]{2}{*}{ Selbuhra } & $2562-4$ & 440 & 81 & 0,1 & 0,14 & 0,8 & 99,02 & 46 & 36 & 2 \\
\hline & $2562-7$ & 440 & 81 & 0,07 & 0,12 & 0,75 & 98,44 & & & \\
\hline \multirow[t]{2}{*}{ Kvirinaki } & 384 & 525 & 60 & 0,46 & 1,1 & 20 & 15,04 & 77 & 31 & $2 ?$ \\
\hline & 385 & $515 ?$ & 63,1 & 0,45 & 0,2 & 20 & 14,96 & & & \\
\hline \multirow[t]{2}{*}{ Klyuchi } & 2 & 370 & 97 & 0,08 & 0,12 & 0,5 & 65,7 & 9 & 3 & 2 \\
\hline & 3 & $390 ?$ & 92,8 & 0,07 & 0,02 & 1,6 & 65,6 & & & \\
\hline Teplovka & & & & & & & & 10 & 5 & 0 \\
\hline Koshak & 104 & 455 & 77,4 & 0,02 & 0,02 & 0,15 & 67,3 & 20 & 13 & 1 \\
\hline \multirow[t]{13}{*}{ Tetritskaro } & $1--1$ & 475 & 72,6 & 0,09 & 0 & 0,17 & 65,5 & 81 & 37 & 13 \\
\hline & $1--4$ & 485 & 70,2 & 0,04 & 0 & 0,02 & 65,5 & & & \\
\hline & 5 & $360 ?$ & 100 & 0,11 & 0 & 0,12 & 65,47 & & & \\
\hline & 6 & $530 ?$ & 59,5 & 0,004 & 0 & 0,1 & 65,45 & & & \\
\hline & 14 & $410 ?$ & 88,1 & 0,02 & 0 & 0,4 & 64,94 & & & \\
\hline & 15 & $635 ?$ & 34,5 & 0,03 & 0 & 1 & 64,81 & & & \\
\hline & 19--1 & 355 & 100 & 0,12 & 0,07 & 1 & 65,51 & & & \\
\hline & 21 & $350 ?$ & 100 & 0,03 & 0,02 & 0,4 & 65,52 & & & \\
\hline & 23 & $350 ?$ & 100 & 0,02 & 0 & 7,6 & 65,54 & & & \\
\hline & 24 & 355 & 100 & 0,21 & 0,05 & 2,6 & 65,58 & & & \\
\hline & 25 & $355 ?$ & 100 & 0,09 & 0 & 1,3 & 65,65 & & & \\
\hline & 39 & $350 ?$ & 100 & 0,06 & 0 & 0,9 & 67,1 & & & \\
\hline & глина б. & 515 & 63,1 & 0,1 & 0 & 0,7 & 65,5 & & & \\
\hline \multirow[t]{7}{*}{ Khalats } & $16-68$ & $350 ?$ & 100 & 0,06 & 0,1 & 3 & 16,4 & 49 & 30 & 7 \\
\hline & $41-68$ & $510 ?$ & 64,3 & 0,13 & 1,5 & 11,5 & 12,35 & & & \\
\hline & $44-68$ & 515 & 63,1 & 0,08 & 0,1 & 8 & 12 & & & \\
\hline & $49-68$ & $510 ?$ & 64,3 & 0,13 & 1 & 12 & 10,95 & & & \\
\hline & $54-68$ & $510 ?$ & 64,3 & 0,14 & 0,3 & 14,5 & 10,4 & & & \\
\hline & $59-68$ & 510 & 64,3 & 0,09 & 0,2 & 10 & 9,5 & & & \\
\hline & $68-68$ & $505 ?$ & 65,5 & 0,18 & 0 & 18 & 2,85 & & & \\
\hline \multirow[t]{5}{*}{ Gams } & $\mathrm{J} 6$ & 355 & 100 & 200 & 0,05 & 50 & 65,5 & 98 & 68 & 2 \\
\hline & $\mathrm{J} 4$ & 355 & 100 & 5 & 0,05 & 2 & 65,5 & & & \\
\hline & J3-1 & 650 & 22 & 0,2 & 0,2 & 5 & 65,5 & & & \\
\hline & J4-1 & 650 & 22 & 0,19 & 0,16 & 6 & 65,5 & & & \\
\hline & T14 & 660 & 27 & 0,09 & 0,1 & 8 & 65,47 & & & \\
\hline
\end{tabular}

Footnote: $T_{C}$ - Curie point of Ni-Fe alloy particles, ${ }^{\circ} \mathrm{C} ; \% \mathrm{Ni}-$ content of nickel in alloy, determined by linear dependence $T_{C}-\mathrm{Ni} ; \mathrm{Ni}-$ percentage of Ni-Fe alloy $\left(10^{-3} \%\right)$ in sample; $\mathrm{Fe}$ - percentage of iron $\left(10^{-3} \%\right)$ in the same sample; MT- percentage of magnetite + titanomagnetite $\left(10^{-3} \%\right)$ in the same sample; $\mathrm{Ma}$ - the age of sediment in the point of selection of the sample; $\mathrm{N}$ - total number measured TMA samples in the given section; $\mathrm{N}$ (Fe) - number of samples in which iron particles are revealed; $\mathrm{N}(\mathrm{Ni})$ - number of samples in which $\mathrm{Ni}-\mathrm{Fe}$ alloy with $T_{C}<670^{\circ} \mathrm{C}$ is found out. 
permanent average composition of iron particles is likely to imply the constancy of the cosmic dust cloud, through which our planet moved. It is important to emphasize that, unlike the concentration of iron in sediments, which depend on re-deposition, the re-deposition does not affect the composition of iron grains.
The time-distribution of iron particles with nickel content close to the modes of the two sets (zero and $5 \% \pm 1 \%$ ) also has no prominent features (Figure 7). It is important to note that their distributions are not correlated with each other (Figure 8). This indicates the different sources of particles of pure iron and iron with nickel addition.

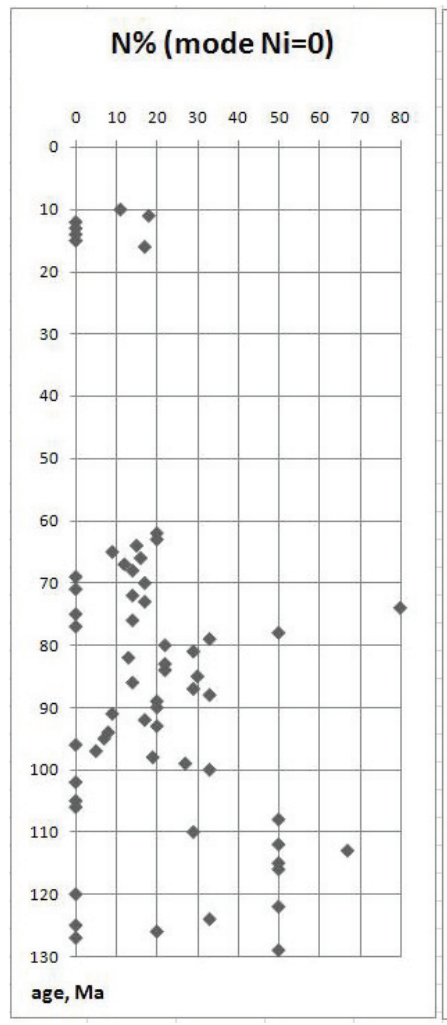

(a)

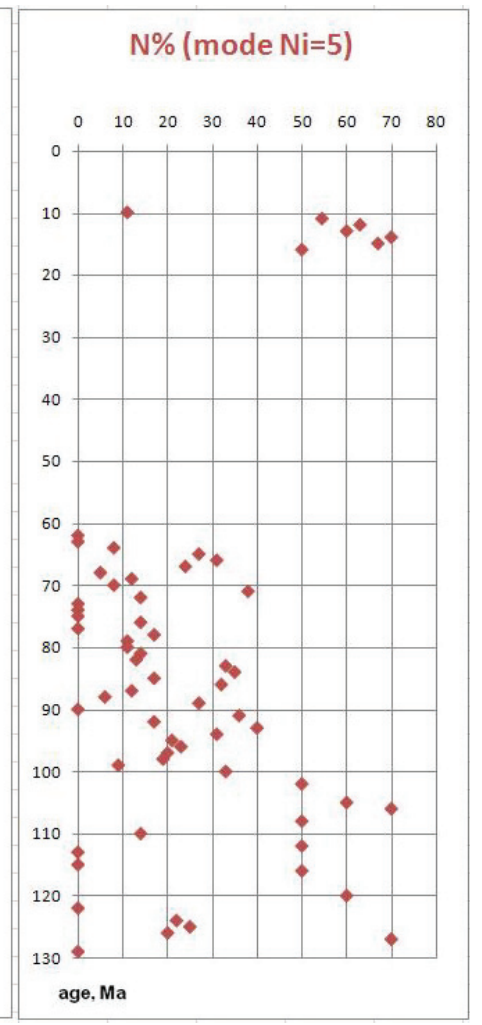

(b)

Figure 7. The distribution of contents of nickel impurity in iron particles, close to modes, depending on age of sediments: (a) Pure iron; (b) Iron with a nickel impurity $5 \pm 1 \%$. The percentage of cases is display in one million years carried to total number of cases in the same one million years interval since the number of the data on one million years considerably varies from units to 70

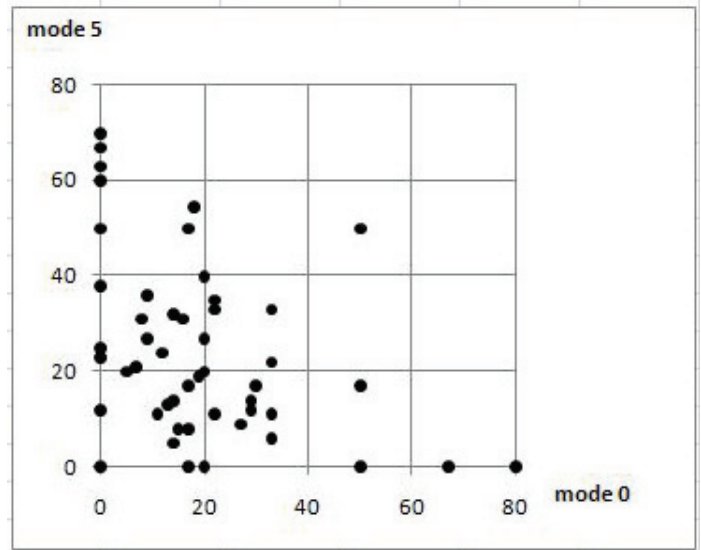

Figure 8. The correlation between number of cases with modal nickel impurity of $0 \%$ and $5 \pm 1 \%$. For comparability of the data on axes the percentage of cases is display in each one million years in relation to total number of the data on the same one million years (see Figure 7) 
During four intervals of global enrichment of sediments by iron, the particles of the second set (Fe with $\mathrm{Ni}$ addition) obviously prevail (Figure 9). The number of cases of pure iron is insignificant and varies from interval to interval: 1) Just one sample with pure iron out 16 TMA data is found for the 10-13 Ma interval. The nickel content varies from $3 \%$ to $10 \%, 5.2 \%$ on average. 2) For the 64-66 Ma interval, pure iron is found in eight cases out of 150 TMA data. The nickel admixture varies from 2 to $34 \%, 7.6 \%$ on average. 3 ) For the interval 84-86 Ma, pure iron is found in twelve cases out of 68 TMA data. The nickel admixture varies from 2 to $20 \%, 8.4 \%$ on average. 4) For the 94-96 Ma interval, pure iron is detected in two cases out of 48 TMA data. The nickel admixture varies from 2 to $20 \%, 8.1 \%$ on average. So, the average nickel contents nearly coincide in the Late Cretaceous intervals and significantly differ in the Miocene.

No correlation between the concentration of iron particles and the nickel content in them is observed ( $\mathrm{r}=$ $-0,024)$. On this background, a peak of enrichment by iron with almost constant nickel content of 5\% is visible, irrespective of the place and age of sediments (Figure 10). This enrichment is found even in Crimea, where the iron content very low (Figure 10). Thus this is a certain global effect.

\section{Conclusions}

The detailed pattern of distribution of native iron particles in place and time during the Cretaceous, Danian and Miocene is discovered with the aid of thermomagnetic analysis up to $800^{\circ} \mathrm{C}$.

The main results of our studies are as follows:

1) The concentration of native iron particles in sediments ranges from $10^{-5} \%$ to $0.05 \%$; they are found in 521 samples out of 921 studied from 15 Cretaceous, Danian and Miocene sections of Austria, Russia (the Volga region, Caucasus), Georgia, Kazakhstan and Turkmenistan. Irrespective of sediment age and locality, their bimodal distribution is typical. The first set with the zero mode includes the sediments, in which iron is not revealed by TMA; the distribution of such deposits in the studied sections is irregular and likely reflects the non-uniformity of iron particle fall. The second set has lognormal distribution with the mode of $0.04-0.15\left(10^{-3} \%\right)$.

2) The global enrichment by iron particles is discovered in Miocene (12-13 Ma), Maastrichtian-Danian (64-66 Ma), Santonian (84-86 Ma) and Cenomanian (94-96 Ma) deposits in the sections more than $1000 \mathrm{~km}$ apart.

The omnipresence of iron particles and global spread

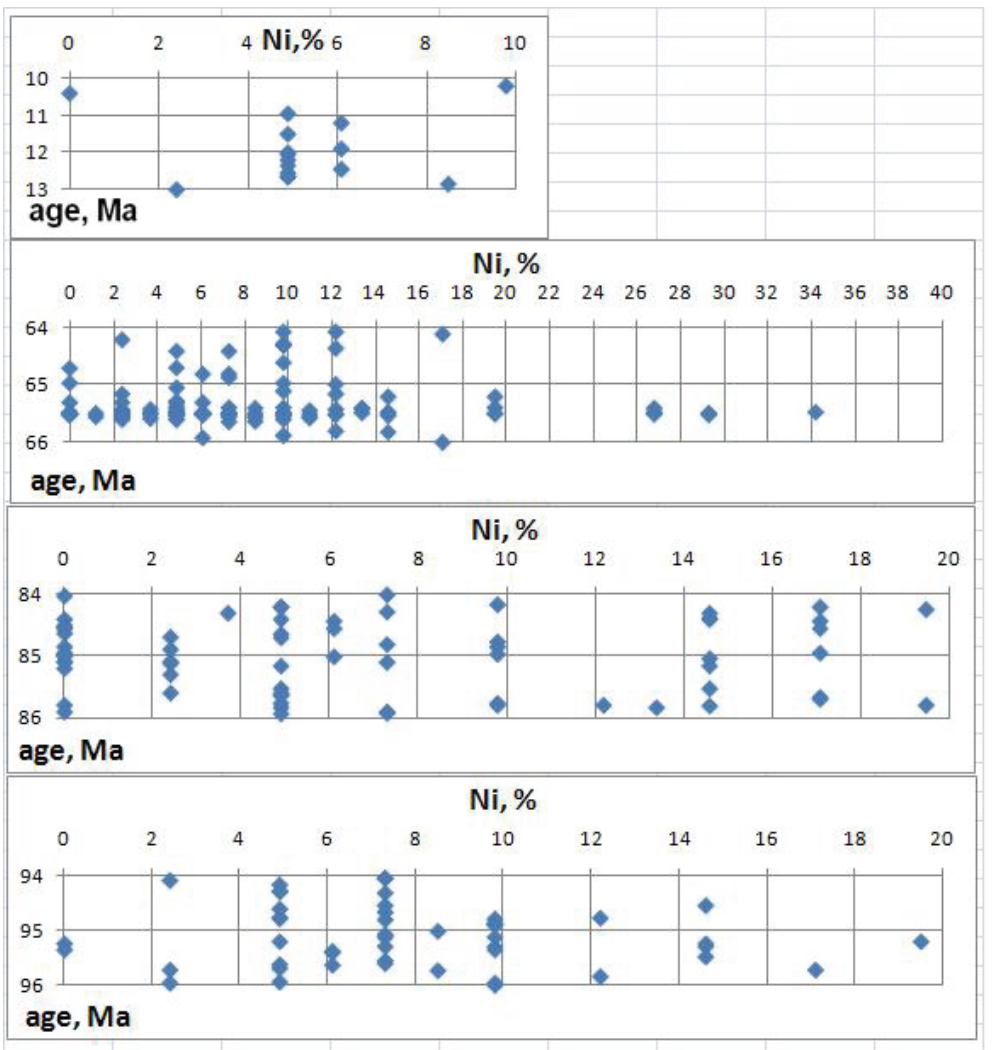

Figure 9. The content of nickel impurity in intervals of global enrichment of iron particles in sediments 


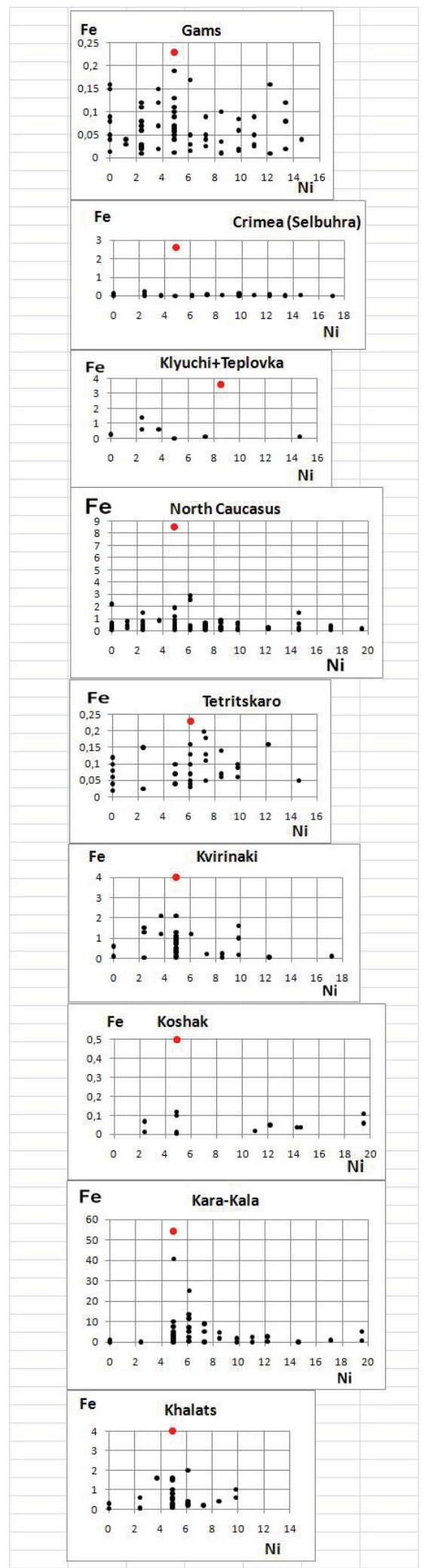

Figure 10. Dependence of nickel impurity in iron particles from their content in the sediment. The maximum concentrations of iron particles are denoted by red color of the above-noted intervals of iron enrichment indicates the cosmic dust as their main source. Iron particles fall to the Earth surface irregularly and probably from different sources, as may be inferred from bimodal distribution of their concentration.

3) Distribution of iron particles composition falls into two sets: the first one corresponds to pure iron without nickel, and the second set has the nearly lognormal distribution with the modal nickel of 5\%. This bimodal distribution implies different origin for of pure iron particles and those with a nickel addition. The lunar rocks are may be the source for the first type. It is worth noting that there are quite few particles with Curie points between $680^{\circ} \mathrm{C}$ and $360^{\circ} \mathrm{C}$; hence the particles of Fe-Ni alloys of such composition are very rare.

The difference in quantities of iron and Ni-Fe alloy particles and the absence of correlation between their contents indicates their different origin. If the first ones are mainly produced by the fall of cosmic dust on the Earth surface, the second ones are possibly connected with meteorites and impact events.

In all cases, it is possible to assert that the possible concentration of Ni-Fe alloy particles is below $10^{-5} \%$ (which is the TMA sensitivity) in the cosmic dust. This conclusion is valid irrespective of the reliability, with which $\mathrm{Ni}-\mathrm{Fe}$ alloy particles are detected.

4) There is no correlation between the concentration of iron particles in sediments and nickel content in them. At the same time, the peak of high iron concentration with the same nickel content of $5 \%$ is found in almost all studied sections irrespective of the location and age of these sediments. Thus it is a certain global effect.

\section{REFERENCES}

[1] A. F. Grachev, O. A. Korchagin, H. A. Kollmann, et al. "The K/T Boundary of Gams (Eastern Alps, Austria) and the Nature of Terminal Cretaceous Mass Extinction," Berichte der Geologischen Bundesanstalt - A, Vol. 78, 2009, p. 199.

[2] E. A. Molostovskii, V. A. Fomin and D. M. Pechersky, "Sedimentogenesis in Maastrichtian-Danian Basins of the Russian Plate and Adjacent Areas in the Context of Plume Geodynamics," Russian Journal of Earth Sciences, Vol. 8, 2006, pp. 1-13.

[3] D. M. Pechersky, "Metallic Iron in Sediments at the Mesozoic-Cenozoic (K/T) Boundary," Russian Journal of Earth Sciences, Vol. 10, 2008, pp. 1-9.

[4] D. M. Pechersky, D. K. Nourgaliev and Z. V. Sharonova, "Magnetolithologic and Magnetomineralogical Characteristics of Deposits at the Mesozoic/Cenozoic Boundary: Koshak Section (Mangyshlak)," Izvestiya, Physics of the Solid Earth, Vol. 42, No. 11, November 2006, pp. 99-102.

[5] D. M. Pechersky, D. K. Nourgaliev and V. M. Trubikhin, "Native Iron in Miocene Sediments," Russian Journal of Earth Sciences, Vol. 10, 2008, pp. 1-11. 
[6] D. M. Pechersky, B. Z. Asanidze, D. K. Nourgaliev and Z. V. Sharonova, "Rock-Magnetism and Magnetostratigraphy of Sediments at the Mesozoic-Cenozoic Boundary: Tetrytskaro Section (Georgia)," Izvestiya, Physics of the Solid Earth, Vol. 45, No. 2, February 2009, pp. 134-145.

[7] D. M. Pechersky, D. K. Nourgaliev, V. A. Fomin, Z. V. Sharonova and D. M. Gilmanova, "Cosmic Iron in the Cretaceous-Danian Sediments," Izvestiya, Physics of the Solid Earth, Vol. 46, No. 12, December 2010.

[8] B. V. Burov, D. C. Nourgaliev and P. G. Yasonov, "Paleomagnetic Analysis," in Russian, Kazan State University Publishers, Kazan, 1986.

[9] R. M. Bozorth, "Ferromagnetism," David Van Nostrand Company Inc., Toronto, 1951.

[10] T. Nagata, M. Funaki and J. Danon, "Magnetic Properties of Tetrataenite-Rich Iron Meteorites," Memoirs of $\mathrm{Na}$ tional Institute of Polar Research, Special Issue, Vol. 41, 1986, pp. 364-370.

[11] N. P. Lyakishev, "Diagrams of the States of Double Metallic Systems," Mashinostroenie, Moscow, Book 1, Vol. 3, 1997.

[12] P. Gorria, D. Martinez-Blanco, M. Pérez, et al., "StressInduced Large Curie Temperature Enhancement in $\mathrm{Fe}_{64} \mathrm{Ni}_{36}$ Invar Alloy," Physical Review, Vol. B80, 2009, pp. 1-6.

[13] T. Nagata and M. Funaki, "Tetrataenite Phase in Antarctic Meteorites," Memoirs of National Institute of Polar Research, Special Issue, Vol. 46, 1987, pp. 245-262.

[14] T. Nagata, J. Danon and M. Funaki, "Magnetic Properties of Ni-Rich Iron Meteorites," Memoirs of National Institute of Polar Research, Special Issue, Vol. 46, 1987, pp. 263-282.

[15] D. E. Brownlee, "Morphological, Chemical and Mineralogical Studies of Cosmic Dust," Philosophical Transactions of the Royal Society London, Vol. A323, 1987, pp. 305-323.

[16] D. W. Parkin, "Cosmic Dust in Antarctic," British Antarctic Survey Bulletin, Vol. 23, 1964.

[17] M. Shima and H. Yabuki, "Study of the Extraterrestrial Material in Antarctica," National Institute of Polar Research, No. 3, March 1988, pp. 53-66.

[18] F. M. Gradstein, J. Ogg and M. van Kranendonk, "On the Geological Time Scale (2008)," Newsletters on Stratigraphy, Vol. 43, No. 1, June 2008, pp. 5-13.

[19] E. A. Molostovskii, D. M. Pechersky and I. Y. Frolov, "Magnetostratigraphic Time Scale of the Phanerozoic and its Description Using a Cumulative Distribution Function," Izvestiya, Physics of the Solid Earth, Vol. 43, No. 10, October 2007, pp. 811-818.

[20] K. B. Doell, C. S. Gromme, A. N. Thorne and F. E. Sentfle, "Magnetic Studies of Lunar Samples," Science, Vol. 167, No. 3918, January 1970, pp. 695-697.

[21] C. E. Helsley, "Magnetic Properties of Lunar Dust and Rock Samples," Science, Vol. 167, No. 3918, January 1970, pp. 693-695.

[22] C. E. Helsley, "Magnetic Properties of Lunar 10022, 10069 , 10084 and 10085 Samples," Proceedings of Apollo 11 Lunar Science Conference, Houston, Vol. 3, 5-8 January 1970, pp. 2213-2216.

[23] A. Larochelle and E. J. Schwarz, "Magnetic Properties of Lunar Sample 10048-22," Science, Vol. 167, No. 3918, January 1970, pp. 700-703.

[24] T. Nagata, Y. Ishikawa, H. Kinoshita, et al., "Magnetic Properties of Lunar Samples," Science, Vol. 167, No. 3918, January 1970, pp. 703-706.

[25] S. K. Runcorn, D. W. Collinson, W. O'Reilly, A. Stephenson, et al., "Magnetic Properties of Lunar Samples," Science, Vol. 167, No. 3918, January 1970, pp. 697-700.

[26] S. K. Runcorn, D. W. Collinson, W. O'Reilly, A. Stephenson, et al., "Magnetic Properties of Lunar Samples," Proceedings of Royal Society of London, Vol. A325, 1971, pp. 157-174.

[27] D. W. Strangway, E. E. Larson and G. H. Pearce, "Magnetic Properties of Lunar Samples," Science, Vol. 167, No. 3918, January 1970, pp. 691-693.

[28] A. M. Reid, C. M. Ir, R. S. Harmon and R. Brett, "Metal Grains in Apollo 12 Igneous Rocks," Earth and Planetary Science Letters, Vol. 9, No. 1, 1970, pp. 1-5.

[29] J. I. Goldstein and H. Yakowitz, "Metallic Inclusions and Metal Particles in the Apollo 12 Lunar Soil," Proceedings of 2nd Lunar Science Conference, Houston, Vol. 1, 11-14 January 1971, pp. 177-191.

[30] H. Wanke, F. Wlotzka, E. Jagoutz and F. Beglmann, "Composition and Structure of Metallic Iron Particles in Lunar Fines," Proceedings of Apollo 11 Lunar Science Conference, Houston, Vol. 1, 5-8 January 1970, pp. 931935.

[31] F. Wlotzka, B. Spettel and H. Wanke, "On the Composition of Metal from Apollo 16 Fines and Meteoritic Component," Proceedings of 4th Lunar Science Conference, Houston, Vol. 2, 5-8 March 1973, pp. 1483-1491. 